\title{
Agriculture and the Generation Problem: Rural Youth, Employment and the Future of Farming
}

\author{
Ben White
}

Abstract Youth unemployment and underemployment are serious problems in most countries, and often more severe in rural than in urban areas. Small-scale agriculture is the developing world's single biggest source of employment, and with the necessary support it can offer a sustainable and productive alternative to the expansion of large-scale, capital-intensive, labour-displacing corporate farming. This, however, assumes a generation of young rural men and women who want to be small farmers, while mounting evidence suggests that young people are uninterested in farming or in rural futures. The emerging field of youth studies can help us understand young people's turn away from farming, pointing to: the deskilling of rural youth, and the downgrading of farming and rural life; the chronic neglect of small-scale agriculture and rural infrastructure; and the problems that young rural people increasingly have, even if they want to become farmers, in getting access to land while still young.

\begin{abstract}
1 Introduction
To consider the future relations between young people, farming and food, various fields of study need to be engaged. A youth studies perspective helps us to understand the lives of young people and their paradoxical turn away from farming in this era of mass rural unemployment and underemployment; it also provides a reminder of the need and the right of young people to be properly researched - not as objects, but as subjects and where possible as participants in research. Agrarian studies helps us to better understand the possible future trajectories of the agri-food sector and in particular the underlying and continuing debate on large- vs. small-scale agricultural futures; and bringing these two perspectives together should help us to understand the intergenerational tensions that we see almost everywhere in rural communities, particularly young people's problems in getting access to farmland and other agriculture-related opportunities in societies where gerontocracy, agrarian inequality and corporate penetration of the agri-food sector, in varying degrees, are the order of the day.
\end{abstract}

2 Rural youth, unemployment, migration and the turn away from farming

One important strength of childhood and youth studies, as they have evolved in recent decades, is their insistence that we study young people in their own right and from their own perspectives, when they have previously been hidden in various applied disciplines such as criminology, social work, health and family studies. Understanding young people's lives requires looking both at how youth is 'constructed' (imagined and represented as a meaningful social, economic and political category), and, also how it is actually experienced by the young. The sometimes wide gap between construction and experience is one key to the understanding of young people. This understanding, however, also requires us to position young people within larger social structures, and this relational dimension has been relatively neglected in the new social studies of childhood and youth. The concepts of generation, ${ }^{1}$ and of social reproduction ${ }^{2}$ help to make this link.

One problem with talking about youth in English is that, unlike many or most other languages, we

IDS Bulletin Volume 43 Number 6 November 2012 (c) 2012 The Author. IDS Bulletin (c) 2012 Institute of Development Studies Published by Blackwell Publishing Ltd, 9600 Garsington Road, Oxford OX4 2DQ, UK and 350 Main Street, Malden, MA 02148, USA 
use the same word with two different meanings: 'youth' as people (like children and adults) and 'youth' as the state or condition of being young (like 'childhood' and 'adulthood'). Theories of youth approach the study of young people in many interesting and useful ways: youth as action, youth as (sub)cultural practice, youth as identity, youth as generation (Jones 2009). Policy discourse on youth tends to view youth (in both its meanings) in a future-oriented way: viewing youth (the people) as 'human capital', and youth (the condition) as typically a period of 'transition'. The World Development Report 2007: Development and the Next Generation (World Bank 2006), for example, sees youth in terms of a set of interlinked transitions - from child to adult, from education to employment, from 'risky behaviours' to responsible citizenship, from dependency in families headed by adults to formation of their own families, and so on. But young men and women do not necessarily agree with either of these ways of looking at youth. They certainly do not (and should not) see themselves as 'human capital', that is, as beings in which the adult world invests, in order to derive some benefits from them in the future. And future-oriented 'transition to adulthood' frameworks tend to obscure the fact that young men and women are also busy in the here and now, developing youth cultures and identities in their own right, that is, trying to be successful as youth and in the eyes of their peers, besides (or sometimes instead of) preparing themselves to be successful adults. ${ }^{3}$

'Youth' as the condition of being young (or of being considered and treated as young in society) tends to last longer than it used to. Rural youth gets prolonged as young people remain enrolled longer in education, their average age at first marriage rises, and their entry into the labour force is postponed. Some countries now define 'youth' in their national laws on youth as up to age 35 or even 40 . Each new generation of rural young men and women now grows up, on the whole, better educated than their parents. But this has not been matched with expansion of employment opportunities for the growing numbers of relatively educated youth. During the past two decades youth unemployment has increased in most world regions. Rural unemployment rates are higher than urban, and youth unemployment rates are typically around twice the adult rate (see, for example, the data for various African countries in Dalla Valle
2012); close to half of all the world's unemployed are youth (World Bank 2006), and many others are underemployed - having insufficient work and/or insecure and poor quality informal sector employment.

There has been some interesting research on the lives and cultures of these globalised, un(der)employed, relatively well-educated youth. Much of this research has focused on young men, and on urban youth, but many of them are of rural origins, and are hanging on in the cities to avoid returning to their villages, where they will be expected to help with farm work and experience subordination to the older generation.

One study in Mali describes the growing phenomenon of thé-chomeurs (literally, the teadrinking unemployed), young men who gather around portable charcoal stoves with teapots and glasses, drinking sweet tea to pass the time. They have had some formal schooling but now cannot obtain the kind of (non-manual) work for which their schooling claimed to have prepared them. They have drifted to a precarious existence in urban sites although there is no work for them, because if they return to the countryside they would be expected to engage in agricultural work (Soares 2010). In urban Ethiopia where youth unemployment rates are estimated at more than 50 per cent, Daniel Mains describes one of the problems young male job seekers have to confront - in contrast to their previous busy lives in school or college - as simply 'the problem of passing excessive amounts of time' (Mains 2007; see also Mains 2011).

These young people are not necessarily idle. They may take on various kinds of casual, shortterm jobs, or help parents in a family enterprise where one exists, but report themselves as 'unemployed' because they are waiting, engaging in odd jobs while looking for what they consider appropriate jobs. We may thus need to introduce a new category of the 'working unemployed'. ${ }^{4}$

In Egypt and other societies of the Middle East region researchers trying to capture this extended transition period during which 'young people wait for pieces of their lives to fall together', have coined the term 'waithood' (Assaad and Ramadan 2008). In the Indian city of Meerut young college graduates, the sons of lower middle-class Jat farmers, enrol in one course of study after 
another, rather than going back to the village, and describe their existence as 'timepass', a kind of purposeless waiting (Jeffrey 2010).

This is not only a sad waste of potential in human terms (or of human capital, for those who insist on seeing young people in that way). It also says something about the irrationality of the economic and political structures in which we live. There is something wrong with a world that allows one-fifth of its young people to be unemployed and countless millions more to be underemployed. The International Labour Organization (ILO) has had the issue of youth unemployment on its agenda since 1935, and UN Millennium Development Goal 8 has as one of its targets to 'develop and implement strategies for decent and productive work for youth'. But neither the ILO, nor other development agencies or national governments, have any idea how to generate 'decent and productive work for youth' on the huge scale which is needed.

The absence of workable ideas on youth employment in the policy world is not surprising. The problems generating mass youth unemployment are structural ones, as every takeover of smaller by larger enterprises, and every investment in new technologies tends to destroy jobs and expel people rather than creating jobs and absorbing them (Bernstein 2004; Li 2009, 2010); this is happening in agriculture and all other sectors, including those where the white-collar jobs used to be located. Structural problems require structural solutions, but in a neoliberal world governments are not inclined to spend money on these things. The young are then forced to improvise their own survival strategies, and this is reflected in current policy shifts away from genuine 'employment generation' to an increasing emphasis on promotion of 'entrepreneurial' skills in World Bank and ILO policy discourse and national youth policies, thus a new kind of 'do-it-yourself' employment strategy for the young. There is little evidence that these policies increase employment prospects or earnings. Young people generally do not have sufficient technical expertise to start a business and would do better to acquire several years of paid work experience, getting to know the ins and outs of their chosen branch of activity before identifying a niche for a new enterprise, and are anyway generally more interested in a paid job in the formal sector.
Where are the needed jobs going to be created? Agriculture is the developing world's single biggest employer and the agri-food sector will certainly grow in the foreseeable future - it has to grow, to fulfil the world's growing demand for food, feed, fuel and fibres (and other crops like tobacco, various legal and illegal drugs, and inputs for the perfume industry) - and if given appropriate support it has the potential to provide decent livelihoods for many more. But agriculture in its present state appears to be so unattractive to young people that they are turning away from agricultural or rural futures. As the Future Agricultures Consortium (2010) concludes for Africa: 'Young Africans are increasingly reluctant to pursue agriculturebased livelihoods'.

To understand better the reasons behind why young people turn away from agriculture we need to take account of a number of problems, including:

- the deskilling of rural youth, and the downgrading of farming and rural life;

- the chronic government neglect of small-scale agriculture and rural infrastructure;

- and the problems that young rural people increasingly have, even if they want to become farmers, in getting access to land while still young.

\section{Deskilling and the assault on rural culture}

Various studies have noted how education as currently practised (particularly secondary education) contributes to a process of 'deskilling' of rural youth in which farming skills are neglected and farming itself downgraded as an occupation. Cindi Katz has described this deskilling process in Sudan's Blue Nile region, based on fieldwork over a 15-year period: those children who had gone to school found themselves both ill-prepared for the kinds of work available locally, and inadequately educated for other kinds of employment (Katz 2004). In wealthy countries we are just beginning to understand what we have lost when manual work becomes devalued and disappears as a component of educational curricula (Crawford 2011).

On the subject of deskilling, it is interesting to note how the idea of young people's 'right to earn a livelihood' has disappeared from international rights discourse. Both The League of 
Nations Declaration of the Rights of the Child (1924) and the Universal Declaration of Human Rights (1948) explicitly stated that children have the right to receive education or training which will enable them to earn a livelihood. But this theme disappeared in later human rights and child rights conventions including the United Nations Convention on the Rights of the Child (1989), in which preparation for earning a livelihood is not mentioned as a goal of education (White 2005).

The alienation of young people from agricultural knowledge and rural life skills is made worse by the misguided political correctness of many anti'child labour' campaigners, who insist on the right of children to complete their entire childhoods without any experience of the world of work. They would thus disagree with Marx, who while recognising that child labour had become an 'abomination' under capitalism, still considered it a 'progressive, sound and legitimate tendency... in [any] rational state of society' for 'children and juvenile persons of both sexes [to] co-operate in the great work of social production', for limited hours and while also going to school - in his vision, from the age of nine to 17 (see Marx 1866). There are many cogent arguments for the importance of work (alongside education) as a part of growing up, and various studies have found that young people who combine school and part-time work have much better chances in labour markets after leaving school. ${ }^{5}$

It is probably no exaggeration to say that in most countries, formal schooling as currently practised teaches young people not to want to be farmers (see, for example, Biriwasha 2012). This is part of a more general downgrading of rural life, an 'assault on rural culture' which goes far beyond education and works through global consumerism and media of all kinds. We should also remember the absence of basic infrastructure in many rural areas, due to decades of neglect in government spending. Basic infrastructure for today's young people includes communications infrastructure. We need to know a lot more about this; even if farming could be made more attractive and profitable and if land could be made available, would rural life still be unattractive to today's globalised young men and women simply because their smartphones don't work there or because of the absence of other facilities and environments which they consider essential components of successful youth? This is actually the easiest part of the problem to take care of, and it will be solved in the not-too-distant future.

Problems of neglected rural infrastructure can be relatively easily overcome. So also, though less easily, can problems of the irrelevance and antirural bias of education, and the alienation of young rural men and women from agricultural work and agricultural knowledge, if educationalists are willing to follow the proposals of the International Fund for Agricultural Development's (IFAD) latest Rural Poverty Report:

A new and broader approach to, and a new emphasis on, agricultural education and training are required $[. .$.$] to provide the next$ generation with the skills, understanding and innovative capacity that they require (IFAD 2010).

But suppose that a new generation of rural school leavers and college graduates do wish to make their futures in 'the great work of social production' in the agri-food sector, and suppose rural schools encourage and support them in this, what are their chances of acquiring a farm when they are ready for it? Today's rural young men and women, even if interested in farming, are confronted by the narrowing and sometimes complete closure of access to land. This may be due to corporate or absentee acquisition of community land; the micro land grabs and 'intimate exclusions' ${ }^{6}$ resulting from local processes of everyday accumulation, land concentration and social divisions that are inherent in agro-commodity production; or simply local gerontocratic structures which give the older generation control of land resources, and make them reluctant to transfer this control to the next generation.

\section{Youth and the global squeeze on farmland}

Large-scale, government-supported corporate acquisition of contested lands and common lands, and the accompanying dispossession of local farmers, pastoralists and forest users is occurring on an unprecedented scale in Africa, Asia, Latin America, and the former Soviet Union, but most particularly in sub-Saharan Africa. ${ }^{7}$

This is not new in the history of the global South or the global North. In the post-colonial decades, however, many governments and agrarian social 
movements attempted to correct these historical distortions by land reforms or other means of breaking up large private or corporate holdings and redistributing them to smallholders. But 'once having nearly disappeared, ... [corporate farming] is now re-emerging everywhere under the aegis of the agro-export model' (van der Ploeg 2008), as governments and international agencies support the acquisition of great expanses of land by large corporations, both foreign and domestic.

While some local elders and local or national elites may become rich by facilitating land dispossession and exclusion, and some adult cultivators may be seduced by immediate cash payments for relinquishing their land, we also need to consider what kind of future these land deals imply for the next generation in rural areas. These deals are usually accompanied by government and corporate promises to develop modern, industrial forms of agricultural production for export, and to provide good jobs and incomes for local people. But research has long ago shown that these industrial (capital- and energy-intensive) forms of agriculture are unsustainable. They also do not provide employment on any significant scale, tending to create enclaves of capitalintensive, monocrop farming with minimal linkages to the local economy. ${ }^{8}$

The World Bank's own report on the global land rush Rising Global Interest in Farmland: Can it Yield Sustainable and Equitable Benefits? (2010) includes 18 commissioned case studies in countries which were expected to provide at least some success stories (including five African cases - the Democratic Republic of Congo, Liberia, Mozambique, Tanzania and Zambia). But these studies only confirmed that corporate land investments are not fulfilling their promise of employment creation for local people, they are environmentally destructive, they disadvantage women, they ignore the proper legal procedures for land acquisition and forcibly displace large numbers of people. But the same report proposes that all these problems of governance, illegality, environmental destruction and so on can be prevented by getting agri-business corporations to sign up to a voluntary code of conduct, in the form of seven 'Principles for Responsible AgroInvestment', to ensure that they will behave more responsibly in the future (World Bank 2010; see also Borras and Franco 2010).
The UN Special Rapporteur on the Right to Food, Olivier De Schutter has become a lone voice within the UN family arguing for a broader vision: 'not to regulate land grabbing as if this were inevitable, but to put forward an alternative programme for agricultural investment', based on reorientation of agricultural systems towards modes of production that are both productive, sustainable and contribute to the progressive realisation of the human right to adequate food. De Schutter therefore argues that:

Land investments implying an important shift in land rights should represent the last and least desirable option, acceptable only if no other investment model can achieve a similar contribution to local development (De Schutter 2011, emphasis added).

A youth and generational perspective adds another powerful reason to De Schutter's arguments. Large-scale land deals (whether for purchase or long lease) should be seen as the 'last and least desirable option' because they close off the smallholder option, not only for today's farmers but also for the next generation, who are completely excluded from decisions made at national or local level which may result in their permanent alienation from land on which they, or their children, might want to farm at some future time.

What about the alternative models? We can think of these in two ways. First, those that involve different and hopefully better relations with agri-business but that do not require, or allow, agri-business corporations to own or lease land on a large scale. Lorenzo Cotula and colleagues have studied and compared several of these alternative 'collaborative business models' which do not involve corporate investment in land (Cotula and Leonard 2010; Vermeulen and Cotula 2010). Looking at the relationship between agri-business and smallholders in terms of 'ownership, voice, risk and rewards', they conclude that the impact on smallholders (good or bad) depends not so much on the form of the relationship but on how it functions in specific contexts. One key ingredient is the willingness of companies to employ the more inclusive business models as a genuine component of their operations rather than just as part of their corporate social responsibility programmes; another, very important in contract farming 
relations, is the negotiating power of smallholders (Vermeulen and Cotula 2010).

Small farmer organisations and movements tend to go further than this. The Via Campesina, for example, claims that smallholders can feed the world, and keep the planet cool, without any need for agri-business involvement, with slogans like 'Land-grabbing causes hunger! Let smallscale farmers feed the world!', and 'Small-scale sustainable farmers are cooling down the earth', and therefore demands: ' 1 . The complete dismantling of agribusiness companies, [and] 2. The replacement of industrialized agriculture and animal production by small-scale sustainable agriculture supported by genuine agrarian reform programmes. ${ }^{9}$

On the technical side, quite authoritative support for smallholder futures comes from the international study of the International Assessment of Agricultural Science and Technology for Development (Agriculture at a Crossroads, IAASTD 2009). This report, which drew on the expertise of about 400 specialists from all over the world, concludes that industrial, largescale monoculture agriculture is unsustainable and must be reconsidered in favour of agroecosystems that combine mixed crop production with conserving water supplies, preserving biodiversity, and improving the livelihoods of the poor in small-scale mixed farming. ${ }^{10}$

Small farmerism of course is not without its own problems. Agrarian structures based on smallscale ('peasant') farming are inherently unstable under conditions of commodity economy, due to the in-built mechanisms of land concentration and agrarian differentiation, which many authors from Lenin onwards have described (Bernstein 2010). But these problems are not impossible to overcome, once we get away from fixations on private ownership titling to other forms of secure individual tenure, subject to maximum holdings and periodic redistribution.

\section{The generational problem in agriculture}

Reflecting on the possibility or impossibility of smallholder futures means looking at the next generation of rural people and specifically the generation problem in agriculture. Traditional agrarian societies are typically sites of patriarchy in both gender and generational relations, reflected in patterns of harsh discipline, and cultural emphasis on respect for the older generation, which are commonly seen in peasant societies worldwide (Stearns 2006). Within these patriarchal structures young people are not passive victims, but exercise a constrained agency. Studies of 'traditional' rural ways of growing up in past times provide examples in which children (both male and female) who wished to farm were allocated a plot of land by parents or other adult relatives, to farm themselves, or engaged in paid work on the farms of others, and controlled to a greater or lesser extent the product of their farming work.

Sixty years ago, among the Tonga in Zimbabwe, Elisabeth Colson found that many children had their own fields. Unmarried boys or girls might be given a portion of a field belonging to either their father or mother before obtaining their own fallowed land, and after harvest might have their own bins in which to store grain from these plots (Colson 1960). A generation later Pamela Reynolds described how young children often work, and are sometimes allowed to make their own farms, on the land of a parent or other relative, and 'actively direct their labour contributions in accord with various strategies that maximise their chances of meeting current needs, and establishing links among kin and neighbours that will enhance future security' (Reynolds 1991).

In how many countries is it still possible for young people to slip themselves into autonomous agricultural production and earning in this way? One reason why young people express a reluctance to farm may reflect their aversion, not to farming as such, but to the long period of waiting that they face before they have a chance to engage in independent farming, even when land is available. In many or most agrarian societies the older generation - parents, or community elders in places where land is controlled not individually but by customary law - retain control of land as long as possible. The tension between the desires of the older generation to retain control of family or community resources, and the desire of young people to receive their share of these resources, form their own independent farms and households, and attain the status of economic and social adulthood, is such a common feature of agrarian societies that it is surprising how neglected it is in research. 
Is it surprising if young men and women today, having experienced some years of education, are reluctant to engage in long years of agrarian 'timepass': who wants to wait until they are 40 or 50 years old to be a farmer? Julian Quan, reviewing changes in intra-family land relations in sub-Saharan Africa notes:

limitations in young people's access to land, land concentration, and land sales and allocations outside the kin group by older generations can become highly problematic where alternative livelihoods are not available, and can trigger wide social conflicts (Quan 2007).

Georges Kouamé provides an example of such conflicts in Côte d'Ivoire, where Abure youth, angered at the way the old men preferred to rent the land out to Burkinabe migrants for pineapple cultivation rather than letting their own young people work it, destroyed the pineapple crops in the field (Kouamé 2010). In Ghana, Kojo Amanor has described how young people engaged in night-time harvesting of oil palm kernels, frustrated at the difficulty of obtaining land now that so much of it had been given over to the Ghana Oil Palm Development Company (GOPDC) plantation: 'The youth... argue that the land belongs to them anyway and was taken away unfairly so they have a right to harvest the fruits' (Amanor 1999). ${ }^{11}$

One important strategy in negotiating youth transitions is young people's mobility, which now extends to all social classes and (in most countries) both genders. These migrations are not always permanent; we need to explore further the phenomenon of cyclical, part-lifetime migration. For young people 'village' (and also 'farm') can come to mean the place where you grow up, which you will leave in search of urban employment, but where you may later leave your children in the care of their grandparents (and in many cases, to care for your grandparents), and where you may later return to be a farmer yourself, and maybe a smarter farmer than your parents, when land becomes available and urban work has maybe provided some capital for improvements.

Paul Richards and Krijn Peters have argued consistently for the need to find ways to make farming a better, a possible and a smarter option for young people in West Africa. Peters (2011), writing on Sierra Leone, describes in detail the mismanagement and stagnation of the agricultural sector, the false hope that education gave young people, and their vulnerability to local seniors, through the elders' control over customary courts, land, agricultural labour and the allocation of marriage partners, in this highly gerontocratic society.

The African rural setting is... inhabited... increasingly by numbers of young people who lack the basic modalities even to be peasants. Marginalized by 'customary' institutional exactions, first begun under colonial rule and maintained by rural elites ever since, [...] They cannot even mobilize their own labour to work the allegedly abundant land, since this would be vulnerable to extraction from them by marriage payments and court fines for infringements of a traditional code of behaviour regulated by elders (ibid.).

He therefore argues that 'the dislike of rural youth [for agriculture] is not focused on agriculture as such, but on their vulnerability, in village conditions, to exploitation by local elites and gerontocrats' (ibid.). Richards argues for '... the need to open up land to more intensive use by making it more readily accessible to young people, free from control by a local gerontocratic order' (Richards 2010). How many governments, international agencies or NGOs have young people's access to land on their policy agendas, as more than rhetoric?

Finally, turning to the often invisible group of rural women and girls: as we know, much of the world's small-scale farming is done by women. More than 30 years ago the UN's CEDAW Convention (UN 1979) - now ratified by all but a few member states - established clearly that women must '.. have access to... equal treatment in land and agrarian reform' (article 14) and also that they must have equal rights in intra-family property transfers through inheritance (article 16). The Chicago Council on Global Affairs recently released a special report on girls in rural economies around the world, noting that girls have the power to transform rural economies, and should be seen as future farmers and major stakeholders in agriculture and natural resource management, which requires among other things 'ensuring equitable 
inheritance and land rights for adolescent girls and women by supporting efforts to change and enforce relevant national and customary laws' (Chicago Council 2011). How many of the studies that found rural youth uninterested in farming asked young women whether they would be interested in being independent farmers, on their own smallholding?

\section{The future of rural youth in agriculture}

Thinking about youth, farming and food raises fundamental questions about the future, both of rural young women and men, and of agriculture itself. As I have tried to indicate, the current debate about 'land grabbing' is in fact a debate about the future shape of farming and the fate of rural populations. If visions of a future based on smallholder-based agriculture are to be realised, and if young people are going to have a place in that future, these problems have to be taken seriously and given much more attention than has been the case in recent policy debate, and in recent research. IFAD's latest Rural Poverty Report, which gave special attention to young people, underlines:

[the need] to turn rural areas from backwaters into places where [young] people have access to quality services and profitable opportunities, and where innovation takes place, whether in agricultural production and marketing, in non-farm enterprises or in energy generation (IFAD 2010).

The issue of intergenerational transfer of land rights - or, when that does not happen, intergenerational dispossession, when one generation's land is sold off which ought to have been passed on to the next - deserves our attention. If we are interested in small farmbased alternatives to industrial capitalist agriculture, there needs to be a generation of rural men and women interested in taking up the challenge.

\section{Notes}

1 Generation: 'the social (or macro-) structure that is seen to distinguish and separate children [and youth] from other social groups, and to constitute them as a social category through... particular relations of division, difference and inequality between categories'
This brings us back to the question of youth agency, and policies towards youth. One fundamental question affecting rural youth futures is simply the question: 'who will own the countryside?' ${ }^{12}$ when today's young men and women reach adulthood. There is something fundamentally worrying about policy contexts which allow older men, in communities, local or national governments to engage in or endorse land transactions which may permanently bar the next generation of young men and women from farming careers, without giving those to be affected any say-so in this process. The establishment of special national Youth Commissions, Ministries of Youth (or Youth and Sports, Women and Youth, or Women Youth and Sports) and Youth branches of Farmers'

Organisations do not always help in this regard; they may even marginalise the discussion of issues which affect youth by taking them out of the mainstream. In such conditions young people may have no option but to invent their own ways of doing politics, as did the predominantly young masses of people who went to the streets and brought down the government of Madagascar in protest against the massive land deal it had made with the South Koreans.

There are real and important choices to be made, with important consequences for the coming generations. Will young men and women still have the option, and the necessary support, to engage in environmentally sound, small-scale, mixed farming, providing food and other needs for themselves, their own society and others in distant places? Or will they face only the choice to become poorly paid wage workers or contract farmers, in an endless landscape of monocrop food or fuel feedstock plantations, on land which used to belong to their parents, or to move to an uncertain existence in the informal sector of already crowded cities? There are no easy answers to these questions, and that is exactly the reason why they deserve a place on research agendas in the coming years.

[i.e. between children/youth and adults] (Alanen 2001; see also Mannheim 1952).

2 Social reproduction: 'The material and discursive practices which enable the reproduction of a social formation (including the relations between social groups) and its members over time' (Wells 2009). 
3 To claim that young people are mainly preoccupied with their transition to successful adulthood is something like saying that young mothers are mainly busy trying to become successful grandmothers, or that retired academics are trying to become successful dead people.

4 This is more or less what Guy Standing means by the young 'precariat' in his recent book (2011).

5 These arguments are summarised in Bourdillon et al. (2010).

6 The phrase is from Hall et al. (2011).

7 Among the standard sources on contemporary 'land grabbing' are various reports available at www.grain.org; Von Braun and MeinzenDick (2009); UN General Assembly (2010a); World Bank (2010); Committee on Food Security (2011); Oxfam (2011) and most recently Anseeuw et al. (2012). The main

\section{References}

Alanen, L. (2001) 'Explorations in Generational Analysis', in L. Alanen and B. Mayall (eds), Conceptualizing Child-Adult Relations, London: Routledge

Amanor, K.J. (2010) 'Family Values, Land Sales and Agricultural Commodification in SouthEastern Ghana', Africa 80.1: 104-25

Amanor, K.J. (1999) Global Restructuring and Land Rights in Ghana: Forest Food Chains, Timber and Rural Livelihoods, Research Report 108, Uppsala: Noriska Afrikainstitutet

Anseeuw, W.; Alden, L.; Wily, L.; Cotula, L. and Taylor, M. (2012) Land Rights and the Rush for Land: Findings of the Global Commercial Pressures on Land Research Project, Rome: International Land Coalition

Assaad, R. and Ramadan, M. (2008) 'Did Housing Policy Reform Curb the Delay in Marriage among Young Men in Egypt?', Middle East Youth Initiative Policy Outlook 1, Dubai: Brookings Institute and Dubai School of Government

Beckford, G. (1972) Persistent Poverty: Underdevelopment in the Plantation Economies of the Third World, New York: Oxford University Press

Bernstein, H. (2010) Class Dynamics of Agrarian Change, Halifax: Fernwood and Sterling VA: Kumarian

Bernstein, H. (2004) “'Changing Before our Very Eyes": Agrarian Questions and the Politics of Land in Capitalism Today', Journal of Agrarian Change 4.1-2: 190-225 findings emerging from these studies are discussed in Cotula (2012).

8 See, for example, Beckford (1972).

9 See various La Via Campesina position papers on http://viacampesina.org.

10 IAASTD (2009). This report is not mentioned in the World Bank Report on Rising Global Interest in Farm Land, although the Bank was one of IAASTD's sponsors. See also the UN Special Rapporteur's report on agro-ecology as a scientific framework to 'facilitate the transition towards a low-carbon, resource-preserving type of agriculture that benefits the poorest farmers' (UN General Assembly 2010b).

11 See also Amanor (2010) for analysis of changing intra-family and intra-generational relations following on commodification in south-eastern Ghana.

12 See White (2011), from which parts of this article are drawn.

Biriwasha, L. (2012) 'Agriculture and the School Curriculum in Zimbabwe', paper presented at International Conference on Young People, Farming and Food: The Future of the Agrifood Sector in Africa, Accra, 19-21 March 2012

Borras, S.M. and Franco, J. (2010) 'From Threat to Opportunity? Problems with the Idea of a "Code of Conduct" for Land-grabbing', Yale Human Rights and Development Law Journal 13: 508-23

Bourdillon, M.; Levison, D.; Myers, W.E. and White, B. (2010) Rights and Wrongs of Children's Work, Series in Childhood Studies, Rutgers NJ: Rutgers University Press

Chicago Council (2011) Girls Grow: A Vital Force in Rural Economies, Chicago ILL: Chicago Council on Global Affairs

Colson, E. (1960) Social Organization of the Gwemba Tonga, Manchester: Manchester University Press

Committee on Food Security (2011) Land Tenure and International Investments in Agriculture, report by the High Level Panel of Experts on Food Security and Nutrition of the Committee on Food Security, Rome: Food and Agriculture Organization

Cotula, L. (2012) 'The International Political Economy of the Global Land Rush: A Critical Appraisal of Trends, Scale, Geography and Drivers', Journal of Peasant Studies 39.3-4: 649-80

Cotula, L. and Leonard, R. (eds) (2010) Alternatives to Land Acquisitions: Agricultural Investment and Collaborative Business Models, 
London: International Institute for Environment and Development (IIED)

Crawford, M. (2011) The Case for Working With Your Hands: Or Why Office Work is Bad for Us and Fixing Things is Good, London: Penguin Books

Dalla Valle, F. (2012) 'Exploring Opportunities and Constraints for Young Agro-entrepreneurs in Africa', paper presented at International Conference on Young People, Farming and Food: The Future of the Agrifood Sector in Africa, Accra, 19-21 March 2012

De Schutter, O. (2011) 'How Not to Think of Land-grabbing: Three Critiques of Largescale Investments in Farmland', Journal of Peasant Studies 38.2: 249-79

Future Agricultures Consortium (2010) 'Future Farmers? Exploring Youth Aspirations for African Agriculture', FAC Policy Brief 037, www.future-agricultures.org (accessed 6 August 2012)

Hall, D.; Hirsch, P. and Murray Li, T. (2011) Powers of Exclusion: Land Dilemmas in Southeast Asia, Singapore: NUS Press

IAASTD (2009) Synthesis Report: Agriculture at a Crossroads: International Assessment of Agricultural Science and Technology for Development, Washington DC: Island Press

IFAD (2010) Rural Poverty Report 2011, Rome: International Fund for Agricultural Development

Jeffrey, C. (2010) Timepass: Youth, Class and the Politics of Waiting in India, Stanford: Stanford University Press

Jones, G. (2009) Youth, Cambridge: Polity Press

Katz, C. (2004) Growing Up Global: Economic Restructuring and Children's Everyday Lives, Minneapolis: University of Minnesota Press

Kouamé, G. (2010) 'Intra-family and Sociopolitical Dimensions of Land Markets and Land Conflicts: The Case of the Abure, Côte d'Ivoire', Africa: The Journal of the International African Institute 80.1: 126-46

Li, T.M. (2010) 'To Make Live or Let Die? Rural Dispossession and the Protection of Surplus Populations', Antipode 41.S1: 66-93

Li, T.M. (2009) 'Exit from Agriculture: A Step Forward or a Step Backward for the Rural Poor?', Journal of Peasant Studies 36.3: 629-36

Mains, D. (2011) Hope is Cut: Youth, Unemployment and the Future in Urban Ethiopia, Philadelphia: Temple University Press

Mains, D. (2007) 'Neoliberal Times: Progress, Boredom, and Shame Among Young Men in Urban Ethiopia', American Ethnologist 34.4: 659-73
Mannheim, K. (1952) 'The Problem of Generations' in P. Kecskemeti (ed.), Karl Mannheim: Essays on the Sociology of Knowledge, London: Routledge

Marx, K. (1866) The Different Questions: Instructions for the Delegates of the Provisional General Council, The International Workingmen's Association, first published in Der Vorbote 10 and 11 (1866) and The International Courier 6/7 and 8/10 (1867), www.marxists.org/archive/marx/works/1866/0/ instructions.htm (accessed 22 August 2012)

Oxfam (2011) 'Land and Power. The Growing Scandal Surrounding the New Wave of Investment in Land', Briefing Paper 151, Oxford: Oxfam

Peters, K.(2011) War and the Crisis of Youth in Sierra Leone, Cambridge: University Press

Quan, J. (2007) 'Changes in Intra-family Land Relations', in Lorenzo Cotula (ed.), Changes in 'Customary' Land Tenure Systems in Africa, London: International Institute for Environment and Development (IIED): 51-63

Reynolds, Pamela (1991) Dance Civet Cat: Child Labour in the Zambezi Valley, London: Zed Books

Richards, P. (2010) 'Do Peasants Need GM Crops?', Journal of Peasant Studies 37.3: 559-74

Soares, B. (2010) “Rasta” Sufis and Muslim Youth Culture in Mali', in Asef Bayat and Linda Herrera (eds), Being Young and Muslim: New Cultural Politics in the Global South and North, Oxford: Oxford University Press: 241-57

Standing, G. (2011) The Precariat: The New Dangerous Class, London: Bloomsbury Academic Stearns, P. (2006) Childhood in World History, London: Routledge

UN (1979) Convention on the Elimination of All Forms of Discrimination against Women, New York: United Nations General Assembly, 34th Session

UN General Assembly (2010a) Report of the Special Rapporteur on the Right to Food, New York: United Nations General Assembly, 65th Session

UN General Assembly (2010b) Report Submitted by the Special Rapporteur on the Right to Food, United Nations General Assembly, Human Rights Council, 16th session, December

van der Ploeg, J.-D. (2008) The New Peasantries: Struggles for Autonomy and Sustainability in an Era of Empire and Globalization, London: Earthscan Vermeulen, S. and Cotula, L. (2010) Making the Most of Agricultural Investment: A Survey of Business Models that Provide Opportunities for Smallholders, London: International Institute for Environment and Development (IIED) 
Von Braun, J. and Meinzen-Dick, R. (2009) "'Land Grabbing" by Foreign Investors in Developing Countries: Risks and Opportunities', IFPRI Policy Brief 13, Washington DC: International Food Policy Research Institute

Wells, K. (2009) Childhood in a Global Perspective, Cambridge: Polity Press

White, B. (2011) 'Who Will Own the

Countryside? Dispossession, Rural Youth and the Future of Farming',Valedictory Address, 59th Dies Natalis of the International Institute of Social Studies, The Hague
White, B. (2005) 'Shifting Positions on Child Labour: The Views and Practice of Intergovernmental Organizations', in Burns Weston (ed.), Child Labour and Human Rights: Making Children Matter, Boulder CO and London: Lynne Rienner

World Bank (2010) Rising Global Interest in Farmland: Can it Yield Sustainable and Equitable Benefits?, Washington DC: World Bank

World Bank (2006) World Development Report 2007: Development and the Next Generation Washington DC: World Bank 